\title{
NOTES
}

\section{Follow the Money: Insulating Agribusiness Through Lobbying and Suppression of Individual Free Speech}

\section{Mallorie McCue*}

\section{INTRODUCTION}

Each year, the global food and beverage industry, made up of food suppliers, manufacturers, and retailers, generates more than $\$ 5.7$ trillion in the business of developing food and selling it for consumption. ${ }^{1}$ To maintain their profit level, agribusiness companies lobby the government, donating nearly $\$ 58$ million to candidates for federal office in the 2010 election cycle alone. $^{2}$ In a time when the health and safety of our food is called into question, one wonders who is protecting the interests of consumers. ${ }^{3}$ With the advent of Citizens United v. FEC, corporations are entitled to greater First Amendment protection than ever before, as the government is prohibited

\footnotetext{
${ }^{*}$ Mallorie A. McCue is a May 2012 graduate of the University of Pittsburgh School of Law. Prior to law school, Ms. McCue earned a B.A. in Public Relations and a B.A. in Women's Studies from the Pennsylvania State University, graduating with distinction. She would like to thank the entire staff of PJEPHL for their work on her note, as well as her family and friends for their unfaltering support and encouragement.

${ }^{1}$ IMAP, FOOD AND BEVERAGE INDUSTRY GLOBAL REPORT 4 (2010), available at http://www.imap.com/imap/media/resources/IMAP_Food_Beverage_Report_WEB_ AD6498A02CAF4.pdf.

2 The CTR. FOR Responsive Politics, Totals By Sector (2010), http://www.opensecrets.org/bigpicture/sectors.php?cycle=2010\&bkdn=DemRep\&sort By=Rank (last visited Jan. 18, 2012).

3 See The Ctr. For Ecoliteracy, Food, Inc. Discussion Guide 81 (2009), available at www.foodincmovie.com/img/downloads/foodinc_PDF_091008.pdf [hereinafter CTR. FOR ECOLITERACY].
} 
Volume 6 Issue 2

Spring 2012

from making distinctions or imposing regulations based upon the identity of the speakers who are exercising their First Amendment rights. ${ }^{4}$ Additionally, the decision set forth that corporations have no cap on spending for the election or defeat of candidates. ${ }^{5}$ President Obama commented that the ruling "opens the floodgates for an unlimited amount of special interest money into our democracy ... giv[ing] lobbyists new leverage to spend millions on advertising to persuade elected officials to vote their way-or to punish those who don't." 6

At the heart of the matter is our First Amendment right to free speech. The First Amendment includes guarantees that Congress will make no law prohibiting or abridging the exercise of freedom of speech, freedom of the press, or the petitioning of the Government for a redress of grievances. Corporations assert that their donations to candidates for public office are an exercise of their right to free speech and further their corporate speech. ${ }^{7}$ However, whistleblowers insist that corporations are not individuals, and should not be protected as such; and that corporate contributions should be limited to protect against corruption. ${ }^{8}$

This Note argues that with Citizens United, special interests such as agribusiness now wield the greatest political and economic power in history, allowing them to further drown individual free speech with agricultural disparagement statutes and lobbying. ${ }^{9}$ Private advocacy nonprofits rely on

${ }^{4}$ Dale Rubin, Corporate Personhood: How the Courts Have Employed Bogus Jurisprudence to Grant Corporations Constitutional Rights Intended for Individuals, 28 QuinNiPIAC L. REV. 523, 550 (2010) (citing Citizens United v. Fed. Election Comm'n, 130 S. Ct. 876, 882-83 (2010)).

${ }^{5}$ Id. at 572-73 (citing Citizens United, $130 \mathrm{~S}$. Ct. at 919).

${ }^{6}$ President Barack Obama, President Obama Vows to Continue Standing Up to the Special Interests on Behalf of the American People, WEEKLY ADDRESS (Jan. 23, 2010), available at http://www.whitehouse.gov/the-press-office/weekly-addresspresident-obama-vows-continue-standing-special-interests-behalf-amer.

${ }^{7}$ Rubin, supra note 4, at 579.

${ }^{8} I d$.

${ }^{9}$ Citizens United v. Fed. Election Comm'n, 130 S. Ct. 876, 883 (2010). 
voluntary donations to enhance the impact of individual voices on elections. Yet corporations can simply make a large, tax-deductible donation to their chosen candidate at a crucial moment in the election, saving or defeating the candidate and preserving their corporate interest. ${ }^{10}$ Paired with corporate practices that emphasize profits over the interests and welfare of the American people, such as utilizing agricultural disparagement statutes, industries such as agribusiness have been granted carte blanche to suppress individual free speech. With unlimited corporate funds flowing to favorable candidates, the ruling has the potential effect of suppressing public opinion by using corporate funding to further agricultural disparagement statutes. Section I will discuss commercial speech, food labeling, and the constitutionality of veggie libel laws, as well their effect of insulating agribusiness from criticism. Section II contains an analysis of Citizens United and its potential effect on agribusiness. Section III sets forth a proposed solution for dulling the impact of Citizens United with transparency, campaign finance reform and disclosure.

\section{COMMERCIAL SPEECH, FOOd LABELING AND THE CONSTITUTIONALITY OF VEGGIE LIBEL LAWS}

\section{A. The First Amendment And Commercial Speech}

Applied to the states through the Fourteenth Amendment, the First Amendment protects commercial speech from unwarranted governmental regulation. ${ }^{11}$ Under the First Amendment's free speech clause, citizens are entitled to seek out or reject certain ideas or influences without government interference or control. ${ }^{12}$ If a statute burdens free speech based on its content, the burden alone is not enough to render it per se unconstitutional, but the presumption of constitutionality usually afforded to congressional enactments

\footnotetext{
${ }^{10} 26$ U.S.C. $\S 501$ (2010).

${ }^{11}$ Cent. Hudson Gas \& Elec. Corp. v. Pub. Serv. Comm'n of N.Y., 447 U.S. 557, 561 (1980) (citing Va. Pharmacy Bd. v. Va. Citizens Consumer Council, Inc., 425 U.S. 748, 761-62 (1976)).

${ }^{12}$ United States v. Playboy Entm't Group, Inc., 529 U.S. 803, 817 (2000).
} 


\section{Volume 6 Issue 2}

Spring 2012

is rebutted, ${ }^{13}$ making it presumptively invalid. ${ }^{14}$ The burden is on the government to rebut that presumption, and if the government does not meet this burden, the law is unconstitutional. ${ }^{15}$

Commercial speech is speech done on behalf of a company or individual with the intent of making a profit such as advertising for the sale of goods and services ${ }^{16}$ or speech proposing a commercial transaction, and is generally not suspect if it is not misleading or related to unlawful activity. ${ }^{17}$ The Constitution generally provides less protection for commercial speech than other constitutionally protected expression. ${ }^{18}$ Rather, the extent of protection is based on the nature of the expression and the nature of the governmental interests served by the regulation of that speech. ${ }^{19}$ As established in Central Hudson Gas \& Electric Corp. v. Public Service Commission of New York, courts considering regulations affecting commercial speech must consider (1) whether the government's interest in restricting the speech is substantial, (2) whether the regulation in question is narrowly tailored to directly advance the government's interest, and (3) whether the regulation is more extensive than necessary to serve that interest. ${ }^{20}$ If a governmental organization seeks to restrict commercial speech, it is not required to employ the least restrictive means conceivable, but, according to the Central Hudson test, it must demonstrate that the harms it asserts are real, that the challenged regulation

${ }^{13} I d$.

${ }^{14}$ Id. (citing R.A.V. v. St. Paul, 505 U.S. 377, 382, 112 S. Ct. 2538, 120 L. Ed. 2d 305 (1992)).

${ }^{15}$ United States v. Playboy Entm't Group, Inc., 529 U.S. 803, 817 (2000).

${ }^{16}$ See, e.g., Thompson v. W. States Med. Ctr., 535 U.S. 357, 388 (2002); Bd. of Tr. of State Univ. of N.Y. v. Fox, 492 U.S. 469, 482 (1989); Bad Frog Brewery, Inc. v. N.Y. State Liquor Auth., 134 F.3d 87, 94 (2d Cir. 1998); United States v. Bell, 238 F. Supp. 2d 696, 703 (M.D. Pa. 2003), aff'd, 414 F.3d 474 (3d Cir. 2005).

${ }^{17}$ Central Hudson, 447 U.S. at 564.

${ }^{18} I d$. at 563.

${ }^{19} I d$.

${ }^{20}$ Rubin v. Coors Brewing Co., 514 U.S. 476, 482 (1995) (citing Central Hudson, 447 U.S. at 563-55). 
directly advances the asserted interest,${ }^{21}$ and that the restriction will in fact "alleviate [the harms] to a material degree." 22 Additionally, the Court "presumes that some accurate information is better than no information at all." ${ }^{23}$ In Rubin v. Coors Brewing the Court reaffirmed the Central Hudson test, holding that the government needed to produce actual evidence, rather than mere speculation or conjecture, to assert that its regulation directly and materially advanced its goals, and was no more extensive than necessary. ${ }^{24}$ In Rubin, the Court affirmed the Tenth Circuit's ruling that 27 U.S.C. $\S 205(\mathrm{e})(\mathrm{ii})$, which prohibited beer labels from indicating alcohol content, was an impermissible infringement of commercial free speech. ${ }^{25}$ In its analysis of the labeling prohibition under Central Hudson, the Court held that the government had a substantial interest - the prevention of beer "strength wars"- to justify the labeling ban. ${ }^{26}$ However, the ban failed under the other prongs of the Central Hudson test, as it was not found to be narrowly tailored to directly advance the government's interest, and was more extensive than necessary to serve that interest. ${ }^{27}$ The Court concluded, "[w]e have no reason to think that strength wars, if they were to occur, would not produce the type of social harm that the Government hopes to prevent." 28

In 44 Liquormart, Inc. v. Rhode Island, the Court upheld the First Amendment protection of commercial speech. ${ }^{29}$ In that case, the Court considered Rhode Island's blanket ban on advertising that informed the public

\footnotetext{
${ }^{21}$ Greater New Orleans Broad. Ass'n, Inc. v. United States, 527 U.S. 173, 188 (1999).

${ }^{22}$ Id.; see also 44 Liquormart, Inc. v. R.I., 517 U.S. 484, 529 (1996) (citing Bd. of Tr. of State Univ. of N.Y. v. Fox, 492 U.S. 469, 480 (1989)).

${ }^{23}$ Rubin v. Coors Brewing Co., 514 U.S. at 482 (citing Central Hudson, 447 U.S. at 562).

${ }^{24} I d$. (citing Rubin, 514 U.S. at 486).

${ }^{25}$ Rubin, 514 U.S. at 486.

${ }^{26} I d$. at 485 .

${ }^{27}$ Id. at 486.

${ }^{28} \mathrm{Id}$. at 485 .

${ }^{29} 44$ Liquormart, Inc. v. R.I., 517 U.S. 484 (1996).
} 


\section{Volume 6 Issue 2}

Spring 2012

about retail prices of alcoholic beverages. ${ }^{30}$ Though the case resulted in a plurality opinion, the principal opinion concluded that while the government had a substantial interest in reducing alcohol consumption, the regulations did not directly advance the governmental interest asserted. ${ }^{31}$ Further, the Court strengthened the evidentiary support requirement of Central Hudson, requiring that the trial court provide findings of fact and "evidentiary support" that the regulation "significantly advanced" the state's interest, and noted that "speculation and conjecture" cannot suffice "when the state takes aim at accurate commercial information for paternalistic ends." ${ }^{32}$

In light of these decisions, the intent of the Supreme Court is clear: the First Amendment protects commercial speech because it serves an informational function. ${ }^{33}$ In contrast, public discourse is protected to ensure forms of participation necessary to sustain democratic legitimacy. ${ }^{34}$ One could argue that the boundaries that separate commercial speech from public discourse reflect sociological judgments about whether particular forms of communication are valued merely as information, or instead as forms of

\footnotetext{
${ }^{30}$ Id. at 489 .

${ }^{31}$ Id. at 507-08 (plurality opinion by Stevens, J., joined by Kennedy, J., Souter, J. and Ginsburg, J.); id. at 532 (O'Connor, J., concurring) ("As a result, even under the less than strict standard that generally applies in commercial speech cases, the State has failed to establish a 'reasonable fit' between its abridgment of speech and its temperance goal. Board of Trustees of State Univ. of N.Y. v. Fox, 492 U.S. 469, 480, 109 S. Ct. 3028, 3034-35, 106 L. Ed. 2d 388 (1989); see also Rubin v. Coors Brewing Co., 514 U.S. at 491, 115 S. Ct. at 1594 (explaining that defects in a federal ban on alcohol advertising are 'further highlighted by the availability of alternatives that would prove less intrusive to the First Amendment's protections for commercial speech'); Linmark, 431 U.S. at 97, 97 S. Ct. at 1620-21 (suggesting that the State use financial incentives or counter-speech, rather than speech restrictions, to advance its interests). It necessarily follows that the price advertising ban cannot survive the more stringent constitutional review that Central Hudson itself concluded was appropriate for the complete suppression of truthful, nonmisleading commercial speech. 447 U.S. at 566 n.9, 100 S. Ct. at 2351 n.9."

${ }^{32}$ Id. at 507 (Stevens, J., plurality).

${ }^{33}$ See Robert Post, Lecture, The Constitutional Status of Commercial Speech, 48 UCLA L. Rev. 1, 14 (2000).

${ }^{34}$ Id. at 4 .
} 
communicative action that embody democratic participation..$^{35}$ The distinction (and thus protection) of commercial speech and public discourse essentially turns on what it means for something to relate "solely" to economic interests, and can be understood to reflect judgments about "the character of the expressive activity" at issue. ${ }^{36}$ This, in turn, implies judgment that inevitably involves an evaluation of the "nature and constitutional significance of the larger social practice within which the activity is embedded." ${ }^{177}$ In his lecture, The Constitutional Status of Commercial Speech, Robert Post highlighted the difference between the protection of commercial speech and of public discourse:

The reason why the First Amendment prohibits the state from suppressing public discourse on the grounds of its persuasiveness is that participation within democratic self-governance is understood to encompass a variety of social relationships, ranging from dialogue to association to persuasion. Within public discourse, speakers seek to persuade others of their point of view and in this way to make the state responsive to their perspective; for the state deliberately to disrupt this communicative relationship is to negate the very constitutional raison d'être of public discourse. ${ }^{38}$

Post concluded that if the government can compel commercial speech, "which is protected to ensure 'the free flow of information and ideas ${ }^{139}[\ldots$ the Court] presumes that the state can diminish a speaker's persuasiveness in order to facilitate the dissemination of accurate information." ${ }^{40}$ But when commercial speech is "threatened" by public discourse, as is the case in

\footnotetext{
${ }^{35} I d$. at 56.

${ }^{36}$ Id. at 18 .

${ }^{37} \mathrm{Id}$.

${ }^{38}$ Id. at 49.

${ }^{39}$ Id. at 49 (quoting Cincinnati v. Discovery Network, Inc., 507 U.S. 410, 426 (1993)).

${ }^{40} I d$.
} 
Volume 6 Issue 2

Spring 2012

agricultural disparagement statutes, the balance of First Amendment protection can be offset, favoring commercial speech over individual public discourse.

\section{B. Agricultural Disparagement Statutes and Their BURDEN ON FREE SPEECH}

In the context of agribusiness, commercial speech concerns a company's advertising and food labeling, which require that specific information, such as ingredients, nutrition data, and allergy information, be printed on a product's label. ${ }^{41}$ The food industry has fought these laws as burdensome and as giving the impression of a problem, and actively lobbies for more favorable standards, as well as for the expansion of food disparagement statutes, or veggie libel laws. ${ }^{42}$ Within the food industry, the government has a compelling interest in protecting the reputation of agribusiness, as it feeds and employs citizens and brings income to the country. However, food disparagement statutes, which make it an actionable tort to criticize food products, are dangerous and unconstitutional because they can suppress free speech by insulating agribusiness from criticism. ${ }^{43}$ Specifically, the threat of being sued under agricultural disparagement statutes, which allow any individual on the spectrum of agribusiness, from grower to manufacturer to proprietor, to utilize the laws, give individuals justifiable fear of meeting the high threshold of proving an allegation by "reasonable and scientific inquiry." ${ }^{44}$

Agricultural disparagement statutes, also known as food libel laws, food disparagement statutes, or veggie libel laws, make it illegal to disseminate misinformation about foods and also make it easier for food companies to sue

\footnotetext{
${ }^{41}$ Lars Noah \& Barbara A. Noah, Note, Liberating Commercial Speech: Product Labeling Controls and the First Amendment, 47 FLA. L. REV. 63, 70-71 (1995); CTR. FOR ECOLITERACY, supra note 3, at 80.

${ }^{42}$ CTR. FOR ECOLITERACY, supra note 3 , at 80.

${ }^{43}$ Colleen Lynch, Note, Disregarding the Marketplace of Ideas: Constitutional Analysis of Agricultural Disparagement Statutes, 18 J.L. \& CoM. 167, 189 (1998).

${ }^{44} I d$. at 181 .
} 
critics. ${ }^{45}$ The elements for a claim of product disparagement are set forth in the Restatement (Second) of Torts, section 623A, which states:

One who publishes a false statement harmful to the interests of another is subject to liability for pecuniary loss resulting to the other if

(a) he intends for publication of the statement to result in harm to interests of the other having a pecuniary value, or either recognizes or should recognize that it is likely to do so, and

(b) he knows that the statement is false or acts in reckless disregard of its truth or falsity. ${ }^{46}$

The burden of proof is on the plaintiff, who must present evidence that demonstrates loss of particular sales; but the standard is often relaxed, allowing plaintiffs to present evidence demonstrating reduced sales after the allegedly disparaging statement. ${ }^{47}$

Certain conditions must be met for a plaintiff to succeed in a common law product disparagement suit. ${ }^{48}$ "First, common-law product disparagement requires the alleged statement be false[,]" ${ }^{49}$ or "not based on reasonable or scientific inquiry." ${ }^{50}$ Truth, therefore, is an absolute defense. ${ }^{51}$ Second, the plaintiff must show that there was a "direct and immediate" relationship between the publication of the statement and resulting damages. ${ }^{52}$ Third, the

\footnotetext{
${ }^{45}$ CTR. FOR ECOLITERACY, supra note 3 , at 80.

${ }^{46}$ RestATEMENT (SECOND) OF TORTS $§ 623$ A (1977).

${ }^{47}$ Lynch, supra note 43, at 168-69.

${ }^{48} I d$. at 169.

${ }^{49} I d$. at 181-82 (citing RESTATEMENT (SECOND) OF TORTS $§ 634$ (1977)).

${ }^{50}$ Id. (citing Ga. Code AnN. § 2-16-1 (Supp. 1998); TeX. Civ. PraC. \& REM. Code ANN. $\S \S 96.001-.004$ (West 1997)).

${ }^{51}$ Id. (citing RESTATEMENT (SECOND) OF TORTS $§ 634$ (1977)).

${ }^{52}$ Id. (citing RESTATEMENT (SECOND) OF TORTS $§ \S 632,633$ (1977)).
} 


\section{Volume 6 Issue 2}

Spring 2012

absolute and conditional privileges available to an individual with privileged information in a defamation suit are also available in a disparagement suit. ${ }^{53}$ As such, a privileged individual can be shielded from liability in a disparagement suit. ${ }^{54}$

Common law defamation is "the unprivileged publication of false and defamatory statements concerning a plaintiff," and can be oral (slander) or written or printed (libel). ${ }^{55}$ The plaintiff must prove that the statement concerned him ("of and concerning requirement"), and that the statement was false and defamatory to his reputation. ${ }^{56}$ Historically, the burden of proof was placed on the plaintiff because courts assume that the plaintiff has greater access to information that would be used to prove that the statement was false. $^{57}$

Advocates of agricultural disparagement statutes claim that such statutes protect the industry from being criticized without substantiation, as well as from the financial impact of such statements. ${ }^{58}$ The stated goals of the laws are to prevent frivolous lawsuits against the food industry ${ }^{59}$ but they can also enable food companies to avoid revealing possibly negative evidence about their practices and suppress individual free speech. For example, in December of 1990, eleven Washington State apple growers, representing some 4,700

${ }^{53} I d$. (citing RESTATEMENT (SECOND) OF TORTS $§ \S 624 \mathrm{cmt}$ a, 635 (1977)).

${ }^{54} \mathrm{Id}$.

${ }^{55}$ Lynch, supra note 43, at 170.

${ }^{56} I d$.

${ }^{57}$ W. Paige Keeton, Defamation and Freedom of the Press, 54 TEX. L. REV. 1221, 1235 (1976) ("A plaintiff is in the best position to know the facts about his own life and activities that will establish falsity. A plaintiff's simple denial would perhaps be sufficient in the abnormal situation of a defendant who publishes statements that conclusively defame without providing some information that would indicate truth. If the defendant included information tending to indicate truth, however, the plaintiff, who has access to the facts of his life, can be expected to discharge the burden of overcoming the suspicious circumstances.").

${ }^{58}$ Lynch, supra note 43, at 179.

${ }^{59}$ Id. at 180 . 
growers in the Washington area, filed a complaint for product disparagement against CBS. ${ }^{60}$ The suit was based on a February 1989 segment from CBS's weekly news show "60 Minutes" on daminozide, a chemical growth regulator sprayed on apples, more commonly known by its trade name, Alar. ${ }^{61}$ The segment was based on a report by the National Resources Defense Council ("NRDC"), entitled Intolerable Risk: Pesticides in Our Children's Food, where researchers found that scientific research had indicated that the chemical breaks down into unsymmetrical dimethylhyrazine ("UDMH"), a carcinogen. ${ }^{62}$ The suit largely concerned a statement by Ed Bradley, a "60 Minutes" commentator, who stated that "[t]he most cancer-causing agent in our food supply is a substance sprayed on apples to keep them on the trees longer and make them look better." ${ }^{63}$ The public's response to this statement and the segment was severe, as sales and prices fell sharply worldwide, amounting to losses as high as $\$ 75$ million dollars. ${ }^{64} \mathrm{CBS}$ was ultimately granted summary judgment in the suit, as the court found that the growers were unable to prove "1) that daminozide was a potent cancer-causing agent, 2) that daminozide was an imminent hazard, and 3) that children were most at risk." ${ }^{65}$ However, the case can be viewed as the impetus for enacting food disparagement statutes, as agricultural companies and their lobbyists began pushing for agricultural disparagement statutes to protect themselves. ${ }^{66}$

Similarly, in 1999 Oprah Winfrey and her guest, vegetarian activist Howard Lyman, were famously sued by Texas beef producers for questioning the safety of hamburger meat. ${ }^{67}$ In the case, Texas cattle ranchers alleged that

\footnotetext{
${ }^{60}$ Auvil v. CBS 60 Minutes, 67 F.3d 816, 818 (9th Cir. 1995).

${ }^{61}$ Id.

${ }^{62} I d$.

${ }^{63}$ Eileen Gay Jones, Forbidden Fruit: Talking About Pesticides and Food Safety in the Era of Agricultural Product Disparagement Laws, 66 BRooK. L. REV. 823, 840 (2001) (citing Auvil v. CBS 60 Minutes, 67 F.3d 816, 818 (9th Cir. 1995)).

${ }^{64}$ Lynch, supra note 43, at 175.

${ }^{65} \mathrm{Id}$. at 177.

${ }^{66} \mathrm{Id}$. at 178 .

${ }^{67}$ Texas Beef Grp. v. Winfrey, 201 F.3d 680, 682 (5th Cir. 2000).
} 
Volume 6 Issue 2

Spring 2012

"one of [Winfrey's] guests knowingly and falsely depicted American beef as unsafe in the wake of the British panic over 'Mad Cow Disease."'68 In the episode, which was titled the "Dangerous Food" show, Winfrey and her guests discussed the epidemic in Britain, symptoms and impacts of the disease, the threat of the disease in the United States, and initiatives started to prevent an outbreak in the U.S. ${ }^{69}$ After the April 1996 broadcast of "Dangerous Food," the cattle market across the U.S., including the Texas Panhandle, declined significantly, ${ }^{70}$ and though a cattle rancher appeared on the Oprah Winfrey Show the following week to refute the claims, ${ }^{71}$ the Texas Beef Group sued under Texas's equivalent of a veggie libel law ${ }^{72}$ in May of $1996 .^{73}$ After making its way through the courts, the Fifth Circuit held in 2000 that though inflammatory and exaggerated, the comments of Winfrey and Lyman were not actionable under the First Amendment because they were based on truthful, established fact. ${ }^{74}$ Though Winfrey and Lyman ultimately won the case, the decision came after four years of legal battle and substantial sums, and led to a palpable censorship. ${ }^{75}$ After the suit was filed, no other program was willing to have Lyman as a guest, for fear of lawsuit. ${ }^{76}$ Additionally, the number of exposés on industry feeding practices declined greatly on shows such as "60 Minutes" and "Geraldo," giving the impression that the Oprah show had gone "too far," and was "irresponsible," and effectively silencing the critics of the meat industry and USDA. ${ }^{77}$

${ }^{68} I d$.

${ }^{69} \mathrm{Id}$. at 683 .

${ }^{70} \mathrm{Id}$. at 684 .

${ }^{71}$ Id.

${ }^{72}$ See Tex. Civ. Prac. \& REM. § 96.002 (2012).

${ }^{73}$ Texas Beef Grp., 201 F.3d at 684.

${ }^{74}$ Id. at $688-89$.

${ }^{75}$ Sheldon Rampton \& John Stauber, One Hundred Percent All Beef Baloney: Lessons from the Oprah Trial, PR WATCH, First Quarter 1998, at 8, 11, available at http:/www.prwatch.org/prwissues/1998Q1/oprah.html.

${ }^{76} \mathrm{Id}$.

${ }^{77} I d$. 
Agricultural disparagement statutes have been passed in thirteen states. ${ }^{78}$ Though the statutes vary in terms of legislative purpose, cause of action, definitions, and potential damages, the statutes of Georgia, Ohio, and Texas exemplify the trend of agricultural disparagement within the U.S. ${ }^{79}$ Under Georgia's statute, agricultural disparagement occurs when an individual willfully or maliciously disseminates "false information that a perishable food product or commodity is not safe for human consumption." ${ }^{80}$ False information is defined as information not based upon "reasonable and reliable scientific inquiry, facts, or data." ${ }^{81}$ Further, any individual in the "entire chain from grower to consumer" may bring an action for damages, ${ }^{82}$ which must be "commenced within two years after the cause of action accrues." ${ }^{83}$ Georgia's legislature clarified their reasoning for the statute:

[T]he production of agricultural and aquacultural food products and commodities constitutes an important and significant portion of the state economy and that it is imperative to protect the vitality of the agricultural and aquacultural economy for the citizens of this state by providing a cause of action for producers, marketers, or sellers to recover damages for the disparagement of any perishable product or commodity. ${ }^{84}$

Ohio uses the same standard for actionable disparagement and has the same statute of limitations as Georgia. ${ }^{85}$ However, Ohio broadens its definition of "false information," defining it as any information "that is not based upon reasonable and reliable scientific inquiry, facts, or data, and that

${ }^{78}$ Lynch, supra note 43, at 178.

${ }^{79} I d$. at $180-83$.

${ }^{80}$ Id. at 180-81 (citing GA. CodE ANN. §2-16-2(1) (Supp. 1998)).

${ }^{81} I d$. at 181 (citing GA. CODE ANN. § 2-16-2(1) (Supp. 1998)).

${ }^{82}$ Id. (citing GA. CODE ANN. §2-16-2(3) (Supp. 1998)).

${ }^{83} I d$.

${ }^{84} I d$. at 180 (citing GA. CODE ANN. §2-16-1 (Supp. 1998)).

${ }^{85}$ Id. at 181 (citing OHIO REV. CODE ANN. §2307.81(A) (West 1996)). 
Volume 6 Issue 2

Spring 2012

directly indicates that a ... product is not safe for human consumption," and provides that any producer or association representing producers may bring an action for damages. ${ }^{86}$ The statute is particularly severe in its provisions for damages. If the plaintiff proves that the defendant knew or should have known dissemination of information was false, the defendants may be awarded compensatory and punitive damages, as well as reasonable attorney's fees and court costs. ${ }^{87}$ Further, any person who intentionally disparages an agricultural product, and does so intending to harm the producers of that product, is liable for treble damages as well. ${ }^{88}$ The reasoning behind the state of Ohio's statute is similar to Georgia's:

[T] he production of agricultural and aquacultural food products constitute an important and significant portion of the economy of this state ... [T] he dissemination ... of false information about the safety of Ohio's food supply would be extremely detrimental to Ohio's economy, the welfare of the consuming public, and the producers of agricultural and aquacultural food products. Accordingly, it is the intent of the general assembly ... to benefit all the citizens of this state and protect the vitality of the agricultural and aquacultural economy by providing a cause of action for producers of perishable ... products to recover damages for the disparagement of such food products. ${ }^{89}$

Texas's disparagement statute was enacted in response to Texas Beef Group v. Winfrey, above. ${ }^{90}$ In contrast with Georgia and Ohio, Texas does not state its purpose or legislative aim. Under the statute, ${ }^{91}$ a person is liable if: "(1) the person disseminates in any manner information relating to a

${ }^{86}$ Id. (citing OHIO Rev. CodE ANN.§ 2307.81(B)(2), (C) (West 1998)).

${ }^{87}$ Id. at 182 (citing OHIO REV. CODE ANN.§ 2307.81(C) West 1998)).

${ }^{88}$ Id. (citing OHIO REV. CODE ANN. $2307.81(\mathrm{E})$ (West 1998)).

${ }^{89}$ OHIO REv. CODE ANN. § 2307.81(A) (West Supp. 2012).

${ }^{90}$ See Tex. Beef Grp., 201 F.3d at 687.

${ }^{91}$ See Tex. Civ. Prac. \& Rem. Code Ann. $§ \S 96.001-.004$ (West 2011). 
perishable food product to the public; (2) the person knows the information is false; and (3) the information states or implies that the perishable food product is not safe for consumption by the public. ${ }^{192}$ To decide whether the disseminated information was false, "the trier of fact shall consider whether the information was based on reasonable and reliable scientific inquiry, facts, or data. ${ }^{93}$ The Texas false disparagement section does not consider punitive damages, providing only for "damages" generally. Rather, the section employs a high standard of culpability for dissemination of the information: "to be liable, the individual must have had actual knowledge or stated or implied that the product was unsafe." ${ }^{94}$ However, the statute does not assign a burden of proof. ${ }^{95}$

Auvil v. CBS 60 Minutes, Texas Beef Group v. Winfrey, and the agricultural disparagement statutes above are just a few examples of the power agribusiness wields. In fact, under current standards, it would be permissible to disseminate false, positive statements as part of commercial speech in food labeling (e.g., "Eating apples will make you live to the age of 100."). ${ }^{96}$ However, it would not be permissible to disseminate true statements that were harmful to agriculture if they were not supported by "a reasonable and scientific inquiry" (e.g. "Chemicals on apples can cause cancer."). ${ }^{97}$ Thus, comments with a positive but false viewpoint toward agriculture can survive, while those critical of agriculture will likely be struck down. This can be viewed as blatant suppression of individual freedom of speech, and is therefore invalid. ${ }^{98}$ Agricultural disparagement statutes were by their very nature designed to relax the burdens of proof allocated for plaintiffs in

92 Tex. Civ. Prac. \& ReM. Code ANN. § 96.002-.003 (West 2011).

${ }^{93}$ Tex. Civ. Prac. \& REM. CODE ANN. § 96.003 (West 2011).

${ }^{94} I d$. at 183 (citing TeX. Civ. PraC. \& REM. Code ANN. § 96.002(b) (West 2011)).

${ }^{95} \mathrm{Id}$.

${ }^{96} \mathrm{Id}$. at 188 .

${ }^{97}$ Id.

${ }^{98}$ Id. at 187 ("These standards create a per se falsity based upon a lack of hard scientific proof and are far below the constitutional requirements.").

P a g e $\mid \mathbf{2 2 9}$ 
Volume 6 Issue 2

Spring 2012

defamation litigation, ${ }^{99}$ while increasing the burden of proof for defendants by requiring that allegations be based on "reasonable and reliable scientific inquiry." ${ }^{100}$ Further, because state agricultural disparagement statutes create a new category of libel solely concerning agriculture, the laws are invalid because states may not privilege certain commodities by prohibiting individuals from exercising their First Amendment rights. ${ }^{101}$

With the Supreme Court decisions on commercial speech in Rubin and 44 Liquormart, and the states' implementation of agricultural disparagement statutes, the "free flow of information and ideas" ${ }^{102}$ now runs only from agribusiness to consumer. By enforcing agricultural disparagement statutes as they currently stand, the state has deliberately disrupted the communicative relationship between buyer and seller, and left individuals unprotected and threatened by the statutes. As a result, individuals may not participate in public discourse, which impacts our democratic legitimacy and the "very constitutional raison d'être of public discourse."103

Similar to Rubin and 44 Liquormart, agricultural disparagement statutes serve a legitimate state interest, but fail in the subsequent prongs of the Central Hudson test. Agricultural disparagement statutes protect the government's legitimate interest in restricting the type of slanderous speech that would unduly harm agribusiness. However, agricultural disparagement statutes are not narrowly tailored to directly advance the government's interest, as the burden of proof that they impose upon the defendant is unduly burdensome, and thus more extensive than necessary to serve the asserted interest. Though the harms that agricultural disparagement statutes seek to protect against are real, rather than speculative, the statutes do not directly achieve the asserted interest, but rather unduly restrict individual free speech

${ }^{99}$ David J. Bederman et al., Of Banana Bills and Veggie Hate Crimes: The Constitutionality of Agricultural Disparagement Statutes, 34 HARV. J. ON LEGIS. 135, 157 (1997).

${ }^{100}$ Id. at 147 .

${ }^{101}$ Id. at 157 .

102 Post, supra note 33, at 49.

${ }^{103} I d$. 
by striking fear in the minds of individuals. In their current state, agricultural disparagement statutes take aim at individuals' legitimate concerns about the health and safety of their food, restricting the amount of information available in a paternalistic and harmful fashion.

Agricultural disparagement statutes should protect against defamation and libel. Using the common law standard, the burden would be on the plaintiff to prove that the alleged "agriculturally-disparaging" statement was false and defamatory to the reputation of agribusiness. In their current state, agricultural disparagement statutes shift the burden to the individual defendant, who likely has less access to the information to support that the statements were not only true, but to meet the higher burden of proof that the statements be "supported by a reasonable and scientific inquiry." This results in an imposition of liability upon individuals for every misstatement, which has the potential to deter not only false speech, but truth as well. Additionally, the possibility that individuals might have to prove everything they question in the spectrum of agribusiness, from the seed, to the farmers, to the board of directors, can lead to self-censorship and the subsequent deprivation of the public to free speech.

\section{Insulating Agribusiness from Criticism}

Agricultural commercial speech has contributed to consumers being unaware of the details of food production, as part of a concerted effort by businesses and lobbyists to craft and protect the image of their products as commercial speech, to hold on to intellectual property, and avoid giving more detailed labels or warnings on their food products. Our romanticized idea of farming is of small farms with blue skies, red barns, and animals grazing in green pastures. But the reality is that industrial factory farms have questionable policies concerning the environment, ${ }^{104}$ animals, ${ }^{105}$ and food

${ }^{104}$ See J.B. Ruhl, Farms, Their Environmental Harms, and Environmental Law, 27 ECOLOGY L.Q. 263, 274-93 (2000).

105 See David J. Wolfson, Beyond the Law: Agribusiness and the Systemic Abuse of Animals Raised for Food or Food Production, 2 ANIMAL L. 123, 125 (1996).

P a g e $\mid \mathbf{2 3 1}$ 
safety. ${ }^{106}$ There is an emphasis on production and profit and de-emphasis on the health and safety of workers and of the product. ${ }^{107}$ In this factory farming model, a single, large agricultural corporation may hire farmers as independent contractors, whereby the farmer's livelihood is dependent on the corporation, which in turn dictates all aspects of production in order to produce a uniform product as efficiently as possible. ${ }^{108}$

Factory farms rely on government subsidies, causing fast, processed food to be cheaper than healthier foods like fruits and vegetables. ${ }^{109}$ Over time, lobbyists have successfully influenced the federal government to spend $\$ 35$ billion each year to subsidize certain commodity crops such as corn and soybeans, which has artificially lowered their prices. ${ }^{110}$ This has resulted in a great amount of encouragement for farmers to grow cheap subsidy crops, which can be used widely in processed foods, and little encouragement to grow specialty crops like fruits and vegetables. ${ }^{111}$ In addition, many past agribusiness employees are current government regulators because of their knowledge of the industry. ${ }^{112}$ However, regulators may face a conflict of interest if they know individuals in the industry. ${ }^{113}$ Though this is the case throughout government, the strength of the American Farm Bureau Federation has become one of the most powerful lobbying forces in the nation, opposing government regulation of farms and providing strength for favorable legislation, including agricultural disparagement statutes. ${ }^{114}$

${ }^{106}$ See James T. O'Reilly, Losing Deference in the FDA's Second Century: Judicial Review, Politics, and A Diminished Legacy of Expertise, 93 CORnEll L. Rev. 939, 946, 949 (2008).

${ }^{107}$ CTR. FOR ECOLITERACY, supra note 3, at 64.

${ }^{108} I d$. at 24 .

${ }^{109}$ Id. at 48 .

${ }^{110} \mathrm{Id}$.

${ }^{111} I d$.

${ }^{112}$ Id. at 81 .

${ }^{113} \mathrm{Id}$.

${ }^{114}$ Ruhl, supra note 104 , at 332. 
Agricultural disparagement statutes are intended to protect producers' businesses and their families, but their effect insulates agribusiness from criticism. ${ }^{115}$ There is a legitimate governmental and collective interest in protecting agriculture, such as "guard[ing] valuable trade secrets, minimiz[ing] unnecessary fear in consumers, which could create panic; and keep[ing] costs down by blocking frivolous lawsuits." ${ }^{116}$ However, when the government allows one perspective on an issue while blocking other perspectives on that issue, it violates the principles of the First Amendment. ${ }^{117}$ Similarly, suppressing individuals' speech because its content reveals detrimental information is contrary to our idea of democracy, as it permits the perspective of agribusiness, while disallowing the perspective of individuals. To consumers, this can be seen as a "veil" that "does more than protect the food system-it protects companies at the expense of consumers." ${ }^{118}$

While protecting our agricultural industry from unfounded defamatory claims is a worthy endeavor, agricultural disparagement statutes suppress free speech, which is vital to the growth of our society, and in turn the safety and health of our food. ${ }^{119}$ First, the amorphous requirements of disparagement and defamation allow any person in the chain of agribusiness to bring a claim for remarks that did not directly concern or harm them. ${ }^{120}$ Thus, the First Amendment is eroded as the statutes suppress the speech of individuals who refrain from bringing claims out of fear that some unidentified and unintended party will institute an action. ${ }^{121}$ Secondly, the standard that the statement is false if not "supported by a reasonable and scientific inquiry" is too high, as it shifts the burden of proving truthfulness to the defendant,

\footnotetext{
115 See Lynch, supra note 43, at 184-85.

${ }^{116}$ CTR. FOR ECOLITERACY, supra note 3 , at 81.

${ }^{117}$ Brielle C. Goldfaden, Comment, "Choose Life" Plates: The States' License to Discriminate Based on Viewpoint, 5 Seton Hall CirCuit ReV. 279, 299 (2008).

${ }^{118}$ CTR. FOR ECOLITERACY, supra note 3 , at 81.

${ }^{119}$ Lynch, supra note 43, at 184.

${ }^{120} I d$. at 185.

${ }^{121}$ Id. at 186.
} 
Volume 6 Issue 2

Spring 2012

which can suppress the free speech of those fearing inability to meet that high burden of proof. ${ }^{122}$ Third, veggie libel statutes suppress specific content of speech - namely, those statements that cannot be supported by "a reasonable and scientific inquiry" and are detrimental to the food industry, and are thus unconstitutional. $^{123}$

\section{Follow THE Money: CITIZENS UNITED V. FEC}

In January 2010, the Supreme Court held in Citizens United v. FEC that the ban on independent corporate funded "electioneering communications" violated the First Amendment on its face. ${ }^{124}$ With this decision, "corporations are now free to make unlimited independent express advocacy expenditures in federal elections." ${ }^{125}$ The case can be seen as disregarding the compelling public interest that political elections are free from the influence of unlimited funding from corporations, as corporations now have greater power than the people, which will allow them to assert their interest and relegate the interests of the people to the sidelines. ${ }^{126}$ With this decision, the Supreme Court has ignored over one hundred years of precedent, disregarding the established compelling governmental interest in preventing "the corrosive and distorting effects of immense aggregations of wealth that are accumulated with the help of the corporate form, and that have little or no correlation to the public's support for the corporation's ideas." ${ }^{127}$ Unlike §501(c)(3) tax-exempt organizations which are prohibited from having any "substantial part" of their activities consist of carrying on propaganda, or otherwise attempting to

${ }^{122} \mathrm{Id}$.

${ }^{123} I d$. at $187-88$.

${ }^{124}$ Citizens United, 130 S. Ct. 876.

${ }^{125}$ Elizabeth Getman, Citizens United: Latest Campaign Finance Decision Creates More Gray Areas, 35-SPG Admin. \& Reg. L. News 13, at 13 (Spring 2010).

${ }^{126}$ Rubin, supra note 4, at 584.

${ }^{127}$ Id. at 550 (citing Austin v. Michigan Chamber of Commerce, 494 U.S. 652, 652 (1990)). 
influence legislation, ${ }^{128}$ Citizens United has granted agribusiness specifically - and corporations in general - an exponential increase of influence in American life, and the near elimination of the power of the state to regulate corporations in their exercise of First Amendment rights. ${ }^{129}$

Viewing the agricultural debate in terms of collectivist and individualist philosophy, Citizens United reflects the deterioration of emphasis on First Amendment rights through a skewed perception of individualist thinking and collectivist thinking. Individualist philosophy encompasses the idea that all people possess rights that predate government, that government's role is to protect those rights completely and without favor, and that rights, or principles, are based on fundamental moral concepts such as justice. ${ }^{130}$ Collectivist thought promotes the idea that free speech is granted by society, agreed upon by its members, and benefits the greater good. ${ }^{131}$ Under the guise of collectivist thinking, the Supreme Court has further strengthened special interest corporations such as agribusiness by easing limits on campaign spending to fund their interests and allowing for the influence of outcomes with electioneering. This decision also tramples individualist thinking by asserting that special interests are on equal footing with individuals concerning free speech, which runs afoul of the principles of fairness and equal justice our country was founded upon.

${ }^{128}$ John J. Silver, Political Activities of Tax-Exempt Nonprofit Organizations: An Overview, 24 COLO. LAW. 2157 (1995).

${ }^{129}$ Rubin, supra note 4, at 584.

${ }^{130}$ Elizabeth Banks Hindman, Note, Protecting Childhood: Rights, Social Goals and the First Amendment in the Context of the Child Online Protection Act, 15 CoMM. L. \& POL'Y 1, 4 (2010).

${ }^{131} I d$. at 5. 


\section{The Solution: Transparency, CaMPaign FinanCe Reform AND DISCLOSURE}

\section{A. Transparency in Agribusiness}

Suing for defamation under agricultural disparagement statutes only promotes the idea that agribusiness is hiding behind a veil. In order to move towards a safer and healthier state of food politics, agribusiness must allow for exercise of individual speech, free from the threat of agricultural disparagement statutes. One would hope that this will lead to food safety activists and agribusiness companies engaging in healthy debate, allowing for research and investigation on the state of farming and food production in our country, improving public policies and allowing consumers to make informed decisions.

\section{B. CAMPaign Finance Reform AND Disclosure}

To remedy the disparity of free speech, Congress must consider passing legislation that blunts the impact of Citizens United and also speaks to the larger problem of special interests dominating the political process. The Fair Elections Now Act (H.R. 1404 and S. 750), which was reintroduced in 2011, would end the reliance on campaign cash from special interests, "allow[ing] federal candidates to choose to run for office without relying on large contributions, big money bundlers, or donations from lobbyists ... [and freeing them] from the constant fundraising in order to focus on what people in their communities want" by establishing a fund for the benefit of candidates who receive support from their states. ${ }^{132}$ To qualify, a candidate would first raise a "large number of small contributions," limited to $\$ 100 .{ }^{133}$ Once the candidate reached 1,500 contributions and a total of $\$ 50,000$, he or she would qualify for Fair Elections funding in the primary, continuing into the general election if the candidate won the primary. ${ }^{134}$

\footnotetext{
132 Summary of Fair Elections Now Act, FAIR Elections Now (Mar. 7, 2012), http://fairelectionsnow.org/about-bill.

${ }^{133} \mathrm{Id}$.

${ }^{134} I d$.
} 
Ten percent of the primary Fair Elections funding would also need to be raised by a U.S. Senate candidate through small contributions, as state populations vary. ${ }^{135}$ This number would be equal to "2,000 plus 500 times the number of congressional districts in [the candidate's] state." ${ }^{136}$ For example, "[a] candidate running for U.S. Senate in Ohio, with 18 districts, would require 11,000 qualifying contributions before receiving Fair Elections funding." ${ }^{137}$ For House candidates, this would amount to $\$ 1,050,000$ in funding, split into forty percent for the primary, and sixty percent for the general. ${ }^{138}$ Senate candidates would receive $\$ 1.25$ million, plus another $\$ 250,000$ per congressional district in each state; split forty percent for the primary, and sixty percent for the general. ${ }^{139}$ If candidates continued to raise small donations from their home state in the general election, they would also be eligible for additional matching Fair Elections funds. ${ }^{140}$ The Fair Elections Fund would contribute five dollars for every dollar raised by donations of $\$ 100$ or less from contributors from the candidate's home state. ${ }^{141}$ In total, the Funds available will be limited to "three times the initial allocation for the primary, and again for the general, available only to candidates who raise a significant amount of small donations from their home state." ${ }^{142}$

Candidates could still utilize political action committees, but would be limited to a $\$ 100$ limit for each individual per year. ${ }^{143}$ Additionally, if a qualifying candidate "is facing a well-financed or self-financed opponent, or is the target of an independent expenditure, they will be able to respond by

\footnotetext{
${ }^{135} \mathrm{Id}$.

${ }^{136} \mathrm{Id}$.

${ }^{137} I d$.

${ }^{138} I d$.

${ }^{139}$ Id.

${ }^{140}$ Id.

${ }^{141}$ Id.

${ }^{142}$ Id.

${ }^{143} I d$.
} 
Volume 6 Issue 2

Spring 2012

utilizing this matching fund provision." ${ }^{144}$ Funding for Senate races would be raised by imposing a small fee on large government contractors, based on a percentage of the contract. Funding for House races "would come from ten percent of revenues generated through the auction of unused broadcast spectrum." ${ }^{145}$ Qualifying candidates would also receive a $20 \%$ reduction in the lowest broadcast rates, while Senate candidates would receive $\$ 100,000$ in media vouchers per congressional district, and House candidates would receive a $\$ 100,000$ media voucher. ${ }^{146}$ Both of these benefits could be exchanged for cash with their national party committee. In total, the new system could cost between $\$ 700$ and $\$ 850$ million per year. ${ }^{147}$

The Fair Elections Now Act supplements the DISCLOSE (Democracy is Strengthened by Casting Light on Spending in Elections) (H.R. 5175 and S. 3628 ) bill, which would mix disclosure and place restrictions on certain types of independent expenditures by requiring organizations involved in political campaigning to disclose the identity of large donors, to reveal their identities in any political ads they fund, and bar foreign corporations, government contractors, and TARP recipients from making political expenditures. ${ }^{148}$ Together, these acts can bring us closer to a more equitable form of campaigning, by reducing our candidates' dependence on corporations and special interests by giving the individual candidate a voice, and requiring transparency. Campaign finance disclosure methods will allow citizens to make informed decisions, as they will be empowered by the release of data through methods such as aggregate disclosure. ${ }^{149}$ Aggregate disclosure obscures the identities of individual donors, protecting against harassment

\footnotetext{
${ }^{144} I d$.

${ }^{145} I d$.

${ }^{146} I d$.

${ }^{147} I d$.

${ }^{148}$ Memorandum from Public Campaign and Common Cause to Editorial Writers and Interested Journalists, regarding The DISCLOSE Act and Fair Elections (Mar. 7, 2012) (on file at http://www.publicampaign.org/pressroom/2010/05/03/memo-thedisclose-act-and-fair-elections).

149 Scott M. Noveck, Note, Campaign Finance Disclosure and the Legislative Process, 47 HARV. J. ON LEGIS. 75, 108 (Winter 2010).
} 
and retaliation, while providing patterns of rich and politically valuable information, which can help to protect against corruption. ${ }^{150}$ This form of disclosure can reveal patterns of political support and help to prevent bribery and retaliation in politics. ${ }^{151}$ Together, the Fair Elections Now Act and the DISCLOSE Act will allow candidates to run competitive races without relying on special interests; once again empowering individuals with free speech by preventing corporations, such as agribusiness, from determining the outcome of elections.

\section{CONCLUSION}

Suppression of individual free speech involves an imbalance of political and legal power, leading one group to have superior speech rights over another. To achieve the freedom of speech that our forefathers envisioned, we must balance the weight placed on individual and corporate free speech, placing limits on corporations to lessen the type of corruption that can arise after Citizens United. By enacting legislation such as the DISCLOSE and Fair Elections Now Acts, we will return to a more equitable form of campaigning, whereby individuals honor "the commitment to robust debate on public issues, which is embodied in the First Amendment, by extending constitutional protection to all discussion and communication involving matters of public or general concern, without regard to whether the persons involved are famous or anonymous." ${ }^{152}$ This will revive full freedom of speech, allowing individuals to freely question food products without fear of punishment under agricultural disparagement statutes.

\footnotetext{
${ }^{150} I d$. at 108 .

${ }^{151} \mathrm{Id}$.

${ }^{152}$ Lynch, supra note 43, at 171 (citing Rosenbloom v. Metromedia, 403 U.S. 29, 44 (1971)).
} 
